\title{
Comparative Study of Follicular Turn Over in Cyclic and Non-Cyclic Murrah Buffaloes through 2D Trans-Rectal Ultrasonography
}

\author{
Gyan Singh $^{1 *}$, R.K. Chandolia ${ }^{2}$, Ravi Dutt ${ }^{2}$, Anil Saini' ${ }^{2}$ Jasmer Dalal ${ }^{2}$ and R.K. Malik ${ }^{3}$ \\ ${ }^{1}$ Teaching Veterinary Clinical Complex, College of Veterinary Sciences, Lala Lajpat Rai \\ University of Veterinary and Animal Sciences, Hisar-125004, Haryana, India \\ ${ }^{2}$ Department of Veterinary Gynaecology and Obstetrics, College of Veterinary Sciences, Lala \\ Lajpat Rai University of Veterinary and Animal Sciences, Hisar-125004, Haryana, India \\ ${ }^{3}$ Department of Veterinary Physiology and Biochemistry, College of Veterinary Sciences, Lala \\ Lajpat Rai University of Veterinary and Animal Sciences, Hisar-125004, Haryana, India \\ *Corresponding author
}

\section{A B S T R A C T}

\section{Keywords \\ 2D ultrasonography, Corpus luteum, Follicle, Murrah buffaloes.}

\section{Article Info}

Accepted: 26 September 2017 Available Online: 10 November 2017
The present research was based on study of follicular dynamics in cyclic $(n=6)$ and noncyclic $(n=6)$ Murrah buffaloes by using 2D trans-rectal ultrasonography from day 1 to 21 of study period. During each examination, number of small $(<4 \mathrm{~mm})$, medium $(4-8 \mathrm{~mm})$ and large follicles $(>8 \mathrm{~mm})$ were assessed along with diameter of medium and large follicles. Moreover, diameter of corpus luteum was also studied daily in cyclic animals. The number of small follicles was significantly $(\mathrm{P}<0.05)$ higher on $6^{\text {th }}$ day $(2.75 \pm 0.25)$ of cycle as compared to number of small follicles on days $4,9,14,16$ and 18-21 of study in cyclic animals. The number of small follicles in non-cyclic buffaloes did not differ significantly $(\mathrm{P}<0.05)$ on day $3(2.00 \pm 0.00), 10(2.00 \pm 0.00)$ and $20(2.00 \pm 0.58)$ of observations but these were significantly higher than other days of study. Significantly higher number of medium size follicles was recorded on $6^{\text {th }}$ day $(4.50 \pm 1.50)$ as compared to day 18 and 20 of study in cyclic animals. But there was no variation in non-cyclic animals throughout the study. The number of large follicles on day $3(1.80 \pm 0.20)$ versus days 15,16 and $18-20$ of study varies significantly $(\mathrm{P}<0.05)$ while on other days there was non-significant variation. The number of large follicles in cyclic animals varied nonsignificantly throughout the study. The diameter of medium sized follicles in cyclic animals on day $5(6.77 \pm 0.42)$ was significantly higher than other days of cycle except days 19 and 20 of the cycle. However, the diameter of medium follicles on $1^{\text {st }}$ day (7.18 $\pm .45 \mathrm{~mm})$ of the study was significantly higher than follicles of days $7,11-13,17-19$ and 21 of study in non-cyclic animals. The diameter of largest follicles recorded between $11.45 \pm 2.35 \mathrm{~mm}$ and $14.12 \pm 1.40 \mathrm{~mm}$ in cyclic and non-cyclic animals, respectively. The large size follicle diameter on $21^{\text {st }}$ day of study was significantly $(\mathrm{P}<0.05)$ higher than the diameter of $6^{\text {th }}$ day while on other days there was non-significant variation in non-cyclic animals. In cyclic buffaloes, CL appeared on $5^{\text {th }}$ day of cycle and attained maximum size on $14^{\text {th }}$ day $(16.43 \pm .40 \mathrm{~mm})$ and then declined. From the present study, it was concluded that the selected non-cyclic animals were not in true anestrus condition as there was follicles development on ovaries that reaches to preovulatory size but not ovulated that may be due to irregular gonadotrophin synthesis or hormonal imbalance and managemental errors. 


\section{Introduction}

In recent years, the capabilities of ultrasound imaging have increased enormously. The application of real time B-mode ultrasonography in bovine reproduction has grown rapidly in the last decade. As ultrasonography is non-invasive technique, therefore, repeated examinations of an animal's reproductive system can be performed without impairing its breeding potential and fetal development. Real time ultrasonographic examination has allowed the monitoring of individual follicle on a daily basis (Fricke, 2002). Ultrasonography has helped in the diagnosis and differentiation of various types of ovarian cyst (Reeves, et al., 1984; Edmondson, etal. 1986; Farin, et al., 1990) and tumours (Kahn and Ludlow, 1989). Ultrasonography also helped in predicting estrus in dairy animals after prostaglandin administration (Smith, et al., 1998). B-mode ultrasonography has a central role in the characterization of ovarian follicular dynamics in the different domestic species and in the development of several protocols to control ovarian function for assisted reproductive technologies (ARTs) such as timed artificial insemination (Adams et al., 2008).

The use of ultrasonography to observe ovarian activity has been reviewed in great detail (Pierson and Ginther, 1988 and Beal et al., 1992). The structures like ovarian follicles, cysts and corpora lutea (CL) have been previously identified by real-time ultrasonography (Kastelic et al., 1990; Beal et al., 1992 and Singh et al., 1997) in cattle. Fricke (2002) reported that follicles are fluidfilled structures which absorb ultrasound waves and are displayed as black on the screen (anechoic or non-echogenic). In contrast, the CL contains varying degrees of dense cells, which reflect the ultrasound waves and result in a gray image on the screen. Linear-array transducers of 5.0 and 7.5 $\mathrm{MHz}$ frequency ranges are most commonly used in cattle, and most of the veterinary ultrasound machines are compatible with probes of different frequencies. Depth of tissue penetration of sound waves and image resolution is dependent upon and inversely related to the frequency of the transducer (Fricke, 2002). An ultrasound machine equipped with a 5.0 $\mathrm{MHz}$ transducer is most useful for bovine practitioners conducting routine reproductive examinations; however, small ovarian structures such as developing follicles are best imaged with a $7.5 \mathrm{MHz}$ transducer. The current study has revealed that ultrasonography is a useful tool in Murrah buffaloes to study follicular dynamics. It was further observed that this technique was easily applicable without any risk to developing dam. Ultrasonography has proved to be a valuable tool in assessing the status of ovarian structures e. g, follicle and corpus luteum in cyclic and non-cyclic buffaloes. For this purpose, trans-rectal ultrasonography was carried out in the buffaloes at a definite interval to assess the nature of cyclicity in buffaloes.

\section{Materials and Methods}

\section{Location}

The present study was conducted on 12 Murrah buffaloes at Buffalo Farm, Department of Livestock Production Management (LPM), College of Veterinary Sciences, Lala Lajpat Rai University of Veterinary and Animal Sciences, Hisar (Haryana).

\section{Experimental plan}

All the animals selected for study were grouped into two having six animals in each: (a) non-cyclic ( $n=6)$ and (b) Cyclic ( $n=6)$. The 
acyclicity of animals was confirmed on the basis of farm record and per rectal examination at 10 days apart.

\section{Ultrasound Machines and Transducers}

The 2D B-mode of ultrasonography was applied for characteristics of follicle and corpus luteum throughout estrous cycle of cyclic and for 21days in non-cyclic animals. Ultrasonography was conducted using Sono Scape S6, portable digital and Toshiba Nemio-XG 3D ultrasound machines. A linear array trans-rectal-transducer having frequency between 5.0 to $7.5 \mathrm{MHz}$ was utilized for 2D ultrasonography for characteristics of follicles and corpus luteum.

\section{Ultrasonographic examination of cyclic and non-cyclic buffalo}

For this, animals were restrained properly without use of any tranquilizing agents; faecal material was removed from the rectum and ovaries were located. Ultrasound jelly was applied over the surface of transducer before its insertion into the rectum. The transducer was moved along the dorsal surface of the reproductive tract and then it was moved laterally to examine the ovaries. Ovaries were scanned by visualizing the structures in each ovary by sliding the transducer from medial to the lateral aspect of the ovary. During each examination, number and diameter of follicles and presence of CL were recorded to facilitate sequential evaluation of follicles turnover. All measurements were made using the built-in, on-screen calipers. Diameters of follicles $>4 \mathrm{~mm}$ were recorded. All ultrasonographic examinations were performed by the same operator.

\section{Observations}

The following parameters were recorded in cyclic and non-cyclic animal groups
Number of small, medium and large size ovarian follicles

Total number of ovarian follicles

Diameter of medium and large size ovarian follicles

Diameter of corpus luteum in cyclic buffaloes

\section{Analysis and interpretation of data}

The ultrasound images recorded in the machine were reviewed in the scanner itself to re-examine the images in detail. The data collected were statistically analyzed by "ANOVA" for finding out average, standard deviation, standard error using computerized SPSS 16.0 software program. The measurements were depicted in the form of tables.

\section{Results and Discussion}

In the present study, the number of small, medium and large follicles varied between $1.00 \pm 0.00 \quad$ to $2.75 \pm 0.25, \quad 2.17 \pm 0.40$ to $4.50 \pm 1.50,1.00 \pm 0.00$ to $1.83 \pm 0.48$ (Table 1) and $1.00 \pm 0.00$ to $2.00 \pm 0.58,1.33 \pm 0.33$ to $2.40 \pm 0.60$ and $1.00 \pm 0.00$ to $1.80 \pm 0.20$ (Table $3)$ in cyclic and non-cyclic animals, respectively. There was non-significant difference $(\mathrm{P}<0.05)$ in number of medium and large size follicles between cyclic and noncyclic buffaloes. Similarly, the diameter of medium and large follicles varied between $4.97 \pm 0.29$ to $6.77 \pm 0.42 \mathrm{~mm}, 9.20 \pm 0.95$ to $11.45 \pm 2.35 \mathrm{~mm}$ (Table 2) and $4.79 \pm 0.21$ to $6.11 \pm 0.40 \mathrm{~mm}, 10.21 \pm 0.64$ to $14.12 \pm 1.40 \mathrm{~mm}$ (Table 4), respectively in cyclic and noncyclic animals. There was non-significant difference $(\mathrm{P}<0.05)$ in diameter of large size follicles between cyclic and non-cyclic buffaloes. The diameter of largest follicles ranged between $11.45 \pm 2.35 \mathrm{~mm}$ (Table 2) and $14.12 \pm 1.40 \mathrm{~mm}$ (Table 4 ) in cyclic and non- 
cyclic animals, respectively. There was significant difference $(\mathrm{P}<0.05)$ in diameter of largest follicles between cyclic and non-cyclic buffaloes.

The mean values of small number of follicles in cyclic animals varied between $1.00 \pm 0.00$ to $2.75 \pm 0.25$ (Table 1). In our study, the number of small follicles was significantly $(\mathrm{P}<0.05)$ higher on $6^{\text {th }}$ day $(2.75 \pm 0.25)$ of cycle as compared to number of small follicles on days 4, 9, 14, 16 and 18-21 of study. The number of small follicles was varied non-significantly $(\mathrm{P}<0.05)$ on other days of study (Table 1$)$. The mean number of medium size follicles in cyclic animals varied between $2.17 \pm 0.40$ to $4.50 \pm 1.50$. In our study, significantly higher number of medium size follicles was recorded on $6^{\text {th }}$ day $(4.50 \pm 1.50)$ as compared to day 18 and 20 of estrous cycle but there was nonsignificant difference on all other days of study (Table 1). The mean number of large follicles in cyclic animals varied between $1.00 \pm 0.00$ to $1.83 \pm 0.48$. The number of large follicles in cyclic animals varied nonsignificantly $(\mathrm{P}<0.05)$ throughout the days of scanning (Table 1).

The mean diameter of medium size follicles in cyclic Murrah buffaloes varied between $4.97 \pm 0.29$ to $6.77 \pm 0.42 \mathrm{~mm}$ (Table 2). The diameter of the follicle on day $5(6.77 \pm 0.42)$ of cycle was significantly higher than other days of cycle except day 19 and 20 of cycle (Table 2). The mean diameter of large size follicles in cyclic Murrah buffaloes varied between $9.20 \pm 0.95$ to $11.45 \pm 2.35 \mathrm{~mm}$ (Table 2). Large size follicles diameter varies nonsignificantly throughout days of study (Table 2).

The mean number of small follicles in noncyclic animals varied between $1.00 \pm 0.00$ to $2.00 \pm 0.58$ (Table 3). The number of small follicles in non-cyclic animals did not differ significantly $(\mathrm{P}<0.05)$ on day $3(2.00 \pm 0.00)$,
$10 \quad(2.00 \pm 0.00)$ and $20 \quad(2.00 \pm 0.58)$ of observations but these were significantly higher than other days of study (Table 3 ). The mean number of medium follicles in noncyclic animals varied between $1.33 \pm 0.33$ to $2.50 \pm 0.87$ (Table 3 ). The number of medium follicles in non-cyclic animals varies nonsignificantly between days 1-21 of study (Table 3). The number (Mean \pm SE) of large follicles in non-cyclic Murrah buffaloes varied between $1.00 \pm 0.00$ to $1.80 \pm 0.20$ (Table $3)$. The number of large follicles on day 3 versus days 15, 16 and 18-20 of study were statistically significant $(\mathrm{P}<0.05)$ while on other days there was non-significant variation (Table 3).

The mean diameter of medium size follicles in non-cyclic Murrah buffaloes varied between $4.79 \pm 0.21$ to $7.18 \pm 0.45 \mathrm{~mm}$ (Table 4). The diameter of follicles on $1^{\text {st }}$ day $(7.18 \pm .45 \mathrm{~mm})$ of the study was significantly higher than the diameter of medium size follicles on days 7, 11-13, 17-19 and 21 of ultrasonographic examinations while on other days there was non-significant variation (Table 4). The mean diameter of large size follicles in non-cyclic animals varied between $10.21 \pm 0.64$ to $14.12 \pm 1.40 \mathrm{~mm}$. The large size follicle diameter on $21^{\text {st }}$ day of study was significantly $(\mathrm{P}<0.05)$ higher than the diameter of $6^{\text {th }}$ day while on other days there was non-significant variation (Table 4).

In non-cyclic and cyclic animals, the total number of follicles varied between $2.83 \pm 0.31$ to $4.83 \pm 0.48$ and $4.00 \pm 0.45$ to $5.67 \pm 0.80$ respectively on different days of study (Table 5).

Total number of follicles was statistically non-significant $(\mathrm{P}<0.05)$ in cyclic and noncyclic animals on different days of study (Table 5). However, total number of follicles was recorded more in cyclic Murrah buffaloes as compare to non-cyclic Murrah buffaloes. 
Diameter of corpus luteum in cyclic buffaloes

The mean \pm SE diameter of $\mathrm{CL}$ varied between $9.36 \pm 0.54$ to $16.43 \pm 0.40 \mathrm{~mm}$ in cyclic Murrah buffaloes (Table 6). The diameter of CL was significantly higher on day 14 as compare to day 5 and 21 of estrous cycle.

In general, more or less there was progressive increment in diameter of CL from day 6 to 14 (Table 6). The mean value of CL diameter was significantly $(\mathrm{P}<0.05)$ lower on day 5 $(9.36 \pm 0.54 \mathrm{~mm})$ than all other days of study (Table 6).

\section{Ovarian dynamics in cyclic buffaloes}

Trans-rectal ultrasonography with linear array transducer having frequency of $5-7.5 \mathrm{MHz}$ was found useful for imaging follicle of different sizes. The follicles were counted, measured and categorized into small $(<4$ $\mathrm{mm})$, medium $(4-8 \mathrm{~mm})$ and large $(>8 \mathrm{~mm})$ as per previous studies (Dutt et al., 2014). It was not possible to measure the follicles having diameter less than $4 \mathrm{~mm}$, therefore their numbers were counted only. The earlier studies using ultrasound revealed that follicular wave begins with emergence of a group of small antral follicles just before the day of ovulation (Ginther et al., 1996).

A second wave of growth emerges approximately day 10 after ovulation and for three-wave cycles, an additional wave emerges at day 16 after ovulation. For both the two and three-wave cycles, the ovulatory follicle arises from the final wave in cattle (Ginther et al., 1996). Aslan et al., (2000) observed the difference in detection of follicles by ultrasound and rectal palpation, opined that ultrasound was more effective at identifying follicles greater than $10 \mathrm{~mm}$ in diameter than rectal palpation. Follicles with
10 to $15 \mathrm{~mm}$ in diameter were detected in $90 \%$ of cases using ultrasonography versus $62 \%$ of the cases using rectal palpation. Follicles greater than $15 \mathrm{~mm}$ were detected with $100 \%$ accuracy by both ultrasonography and rectal palpation. Manual diagnosis of follicles $<10 \mathrm{~mm}$ is generally inaccurate and ultrasound offers the possibility to diagnose the follicles <5 mm (Hanzen et al., 2000). In present study, follicles around $4 \mathrm{~mm}$ were detected trans-rectally through real time 2D ultrasonography.

The mean number of small follicles in cyclic animals varied between $1.00 \pm 0.00$ to $2.75 \pm 0.25$. In current investigation, the maximum number of small follicles was recorded on 6th and 17th day of cycle indicating initiation of new follicular wave. Differences between follicles number during the cycle were due to the emergence of small follicles (beginning of wave) and their growth and regression. It is similar to study done in Egyptian buffaloes (Baruselli et al., 1997). Manik et al., (1999) reported no significant difference in number of small follicles in control animals on various days of estrous cycle in cyclic buffaloes. Akshey et al., (2005) observed that there was no difference in cyclic Murrah buffaloes in the number of small follicles between day 3 and day 5 . Yilmaz et al., (2014) reported that the number of follicles $<5 \mathrm{~mm}$ in diameter showed no significant difference throughout the estrous cycle in water buffaloes.

In present study, significantly higher number of medium size follicles was recorded on $6^{\text {th }}$ day $(4.50 \pm 1.50)$ as compared to day 18 and 20 of estrous cycle but there was non-significant difference on all other days of study. Barkawi et al., (2009) observed maximum number of follicles that had diameters $\geq 4 \mathrm{~mm}$ was detected between days 3 and 7 of the estrous cycle in both normal and uterine pathology associated in Egyptian buffaloes. 
Table.1 Number (Mean \pm SE) of small $(<4 \mathrm{~mm})$, medium $(4-8 \mathrm{~mm})$ and large ovarian follicles $(>8 \mathrm{~mm})$ in cyclic Murrah buffaloes on various days of estrous cycle

\begin{tabular}{|c|c|c|c|}
\hline Days of estrous cycle & Number of small follicles & Number of medium follicles & Number of large follicles \\
\hline 1 & $1.33 \pm 0.33^{\text {abcde }}$ & $3.50 \pm 0.64^{\mathrm{ab}}$ & $1.00 \pm 0.00$ \\
\hline 2 & $2.00 \pm 0.70^{\text {bcde }}$ & $3.80 \pm 0.37^{\mathrm{ab}}$ & $1.33 \pm 0.33$ \\
\hline 3 & $2.00 \pm 0.44^{\mathrm{de}}$ & $4.20 \pm 0.80^{\mathrm{ab}}$ & $1.50 \pm 0.50$ \\
\hline 4 & $1.00 \pm 0.00^{\mathrm{ab}}$ & $4.20 \pm 0.58^{\mathrm{ab}}$ & $1.40 \pm 0.24$ \\
\hline 5 & $1.75 \pm 0.48^{\text {abcde }}$ & $3.00 \pm 0.91^{\mathrm{ab}}$ & $1.40 \pm 0.24$ \\
\hline 6 & $2.75 \pm 0.25^{\mathrm{e}}$ & $4.50 \pm 1.50^{b}$ & $1.50 \pm 0.22$ \\
\hline 7 & $2.00 \pm 0.58^{\text {bcde }}$ & $3.40 \pm 0.68^{\mathrm{ab}}$ & $1.67 \pm 0.33$ \\
\hline 8 & $1.50 \pm 0.22^{\text {cde }}$ & $3.20 \pm 0.49^{\mathrm{ab}}$ & $1.00 \pm 0.00$ \\
\hline 9 & $1.00 \pm 0.00^{\mathrm{ab}}$ & $2.50 \pm 1.50^{\mathrm{ab}}$ & $1.00 \pm 0.00$ \\
\hline 10 & $1.67 \pm 0.33^{\text {abcde }}$ & $3.00 \pm 0.84^{\mathrm{ab}}$ & $1.60 \pm 0.24$ \\
\hline 11 & $1.50 \pm 0.29^{\mathrm{abcde}}$ & $3.00 \pm 0.58^{\mathrm{ab}}$ & $1.33 \pm 0.21$ \\
\hline 12 & $1.25 \pm 0.25^{\mathrm{abcde}}$ & $2.50 \pm 0.56^{\mathrm{ab}}$ & $1.33 \pm 0.21$ \\
\hline 13 & $1.25 \pm 0.25^{\mathrm{abcde}}$ & $2.83 \pm 0.48^{\mathrm{ab}}$ & $1.50 \pm 0.22$ \\
\hline 14 & $1.50 \pm 0.50^{\mathrm{abcd}}$ & $3.00 \pm 0.55^{\mathrm{ab}}$ & $1.17 \pm 0.31$ \\
\hline 15 & $1.40 \pm 0.24^{\mathrm{abcde}}$ & $3.20 \pm 0.20^{\mathrm{ab}}$ & $1.40 \pm 0.40$ \\
\hline 16 & $1.50 \pm 0.50^{\mathrm{abcd}}$ & $3.75 \pm 0.48^{\mathrm{ab}}$ & $1.50 \pm 0.29$ \\
\hline 17 & $2.00 \pm 0.00^{\mathrm{abcde}}$ & $2.60 \pm 0.51^{\mathrm{ab}}$ & $1.20 \pm 0.20$ \\
\hline 18 & $1.00 \pm 0.00^{\mathrm{ab}}$ & $2.33 \pm 0.49^{\mathrm{a}}$ & $1.50 \pm 0.22$ \\
\hline 19 & $1.00 \pm 0.00^{\mathrm{ab}}$ & $2.67 \pm 0.42^{\mathrm{ab}}$ & $1.83 \pm 0.48$ \\
\hline 20 & $1.00 \pm 0.00^{\mathrm{ab}}$ & $2.17 \pm 0.40^{\mathrm{a}}$ & $1.67 \pm 0.21$ \\
\hline 21 & $1.00 \pm 0.00^{\mathrm{ab}}$ & $2.50 \pm 0.22^{\mathrm{ab}}$ & $1.40 \pm 0.24$ \\
\hline
\end{tabular}

Note: Mean values with different superscripts $(\mathrm{a}, \mathrm{b}, \mathrm{c}, \mathrm{d}, \mathrm{e})$ differ significantly $(\mathrm{P}<0.05)$

Mean values without superscripts did not differ significantly $(\mathrm{P}<0.05)$

Table.2 Diameter (Mean \pm SE) of medium $(4-8 \mathrm{~mm})$ and large $(>8 \mathrm{~mm})$ size follicles in cyclic Murrah buffaloes on various days of estrous cycle

\begin{tabular}{|c|c|c|}
\hline Days of estrous cycle & Diameter of medium follicles(mm) & Diameter of large follicles (mm) \\
\hline 1 & $5.46 \pm 0.42^{\mathrm{ab}}$ & $9.20 \pm 0.95$ \\
\hline 2 & $4.97 \pm 0.29^{\mathrm{a}}$ & $9.72 \pm 0.87$ \\
\hline 3 & $5.39 \pm 0.12^{\mathrm{ab}}$ & $9.85 \pm 0.15$ \\
\hline 4 & $5.56 \pm 0.35^{\mathrm{abc}}$ & $9.40 \pm 0.48$ \\
\hline 5 & $6.77 \pm 0.42^{\mathrm{d}}$ & $9.52 \pm 0.52$ \\
\hline 6 & $5.75 \pm 0.15^{\mathrm{abc}}$ & $9.60 \pm 0.27$ \\
\hline 7 & $5.79 \pm 0.27^{\mathrm{abc}}$ & $9.60 \pm 0.82$ \\
\hline 8 & $5.08 \pm 0.30^{\mathrm{a}}$ & $11.45 \pm 2.35$ \\
\hline 9 & $5.68 \pm 0.20^{\mathrm{abc}}$ & $10.85 \pm 0.83$ \\
\hline 10 & $5.21 \pm 0.23^{\mathrm{ab}}$ & $10.68 \pm 0.85$ \\
\hline 11 & $5.18 \pm 0.39^{\mathrm{ab}}$ & $9.91 \pm 0.53$ \\
\hline 12 & $5.45 \pm 0.22^{\mathrm{ab}}$ & $10.43 \pm 0.88$ \\
\hline 13 & $5.10 \pm 0.25^{\mathrm{a}}$ & $10.14 \pm 0.61$ \\
\hline 14 & $5.37 \pm 0.17^{\mathrm{ab}}$ & $10.47 \pm 0.23$ \\
\hline 15 & $5.25 \pm 0.23^{\mathrm{ab}}$ & $10.34 \pm 0.27$ \\
\hline 16 & $5.47 \pm 0.38^{\mathrm{ab}}$ & $10.65 \pm 0.45$ \\
\hline 17 & $5.74 \pm 0.23^{\mathrm{abc}}$ & $9.33 \pm 0.37$ \\
\hline 18 & $5.30 \pm 0.32^{\mathrm{ab}}$ & $9.45 \pm 0.48$ \\
\hline 19 & $6.50 \pm 0.28^{\mathrm{cd}}$ & $10.12 \pm 0.53$ \\
\hline 20 & $6.21 \pm 0.22^{\mathrm{bcd}}$ & $10.14 \pm 0.59$ \\
\hline 21 & $5.82 \pm 0.27^{\mathrm{abc}}$ & \\
\hline
\end{tabular}

Note: Mean values with different superscripts $(\mathrm{a}, \mathrm{b}, \mathrm{c}, \mathrm{d})$ differ significantly $(\mathrm{P}<0.05)$ Mean values without superscripts did not differ significantly $(\mathrm{P}>0.05)$ 
Table.3 Number (Mean \pm SE) of small $(<4 \mathrm{~mm})$, medium $(4-8 \mathrm{~mm})$ and large $(>8 \mathrm{~mm})$ follicles in non-cyclic Murrah buffaloes on various days of ultrasonographic examinations

\begin{tabular}{|c|c|c|c|}
\hline Days of ultrasonographic examinations & Number of small follicles & Number of medium size follicle & Number of large follicles \\
\hline 1 & $1.00 \pm 0.00^{\mathrm{a}}$ & $1.80 \pm 0.49^{\mathrm{a}}$ & $1.60 \pm 0.24^{\mathrm{ab}}$ \\
\hline 2 & $1.00 \pm 0.00^{\mathrm{a}}$ & $2.50 \pm 0.29^{\mathrm{a}}$ & $1.40 \pm 0.24^{\mathrm{ab}}$ \\
\hline 3 & $2.00 \pm 0.00^{\mathrm{b}}$ & $1.50 \pm 0.50^{\mathrm{a}}$ & $1.80 \pm 0.20^{\mathrm{b}}$ \\
\hline 4 & $1.00 \pm 0.00^{\mathrm{a}}$ & $1.60 \pm 0.24^{\mathrm{a}}$ & $1.20 \pm 0.20^{\mathrm{ab}}$ \\
\hline 5 & $1.00 \pm 0.00^{\mathrm{a}}$ & $1.83 \pm 0.65^{\mathrm{a}}$ & $1.17 \pm 0.17^{\mathrm{ab}}$ \\
\hline 6 & $1.50 \pm 0.50^{\mathrm{a}}$ & $2.00 \pm 0.52^{\mathrm{a}}$ & $1.50 \pm 0.34^{\mathrm{ab}}$ \\
\hline 7 & $1.00 \pm 0.00^{\mathrm{a}}$ & $2.17 \pm 0.40^{\mathrm{a}}$ & $1.33 \pm 0.21^{\mathrm{ab}}$ \\
\hline 8 & $1.00 \pm 0.00^{\mathrm{a}}$ & $1.33 \pm 0.21^{\mathrm{a}}$ & $1.50 \pm 0.22^{\mathrm{ab}}$ \\
\hline 9 & $1.00 \pm 0.00^{\mathrm{a}}$ & $1.50 \pm 0.22^{\mathrm{a}}$ & $1.50 \pm 0.24^{\mathrm{ab}}$ \\
\hline 10 & $2.00 \pm 0.00^{\mathrm{b}}$ & $1.75 \pm 0.25^{\mathrm{a}}$ & $1.25 \pm 0.25^{\mathrm{ab}}$ \\
\hline 11 & $1.00 \pm 0.00^{\mathrm{a}}$ & $2.50 \pm 0.87^{\mathrm{a}}$ & $1.33 \pm 0.21^{\mathrm{ab}}$ \\
\hline 12 & $1.00 \pm 0.00^{\mathrm{a}}$ & $1.60 \pm 0.24^{\mathrm{a}}$ & $1.50 \pm 0.29^{\mathrm{ab}}$ \\
\hline 13 & $1.50 \pm 0.28^{\mathrm{a}}$ & $2.00 \pm 0.63^{\mathrm{a}}$ & $1.33 \pm 0.33^{\mathrm{ab}}$ \\
\hline 14 & $1.00 \pm 0.00^{\mathrm{a}}$ & $2.40 \pm 0.60^{\mathrm{a}}$ & $1.00 \pm 0.00^{\mathrm{a}}$ \\
\hline 16 & $1.33 \pm 0.33^{\mathrm{a}}$ & $2.33 \pm 0.56^{\mathrm{a}}$ & $1.00 \pm 0.00^{\mathrm{a}}$ \\
\hline 17 & $1.50 \pm 0.50^{\mathrm{a}}$ & $1.83 \pm 0.40^{\mathrm{a}}$ & $1.17 \pm 0.17^{\mathrm{ab}}$ \\
\hline 18 & $1.00 \pm 0.00^{\mathrm{a}}$ & $1.60 \pm 0.40^{\mathrm{a}}$ & $1.00 \pm 0.00^{\mathrm{a}}$ \\
\hline 19 & $1.00 \pm 0.00^{\mathrm{a}}$ & $1.33 \pm 0.33^{\mathrm{a}}$ & $1.00 \pm 0.00^{\mathrm{a}}$ \\
\hline 21 & $1.00 \pm 0.00^{\mathrm{a}}$ & $1.40 \pm 0.24^{\mathrm{a}}$ & $1.00 \pm 0.40^{\mathrm{a}}$ \\
\hline
\end{tabular}

Note: Mean values with superscripts $(\mathrm{a}, \mathrm{b})$ differ significantly $(\mathrm{P}<0.05)$

Table.4 Diameter (Mean $\pm \mathrm{SE}$ ) of medium $(4-8 \mathrm{~mm})$ and large $(>8 \mathrm{~mm})$ size follicles in noncyclic Murrah buffaloes on various days of ultrasonographic examinations

\begin{tabular}{|c|c|c|}
\hline $\begin{array}{c}\text { Days of ultrasonographic } \\
\text { examinations }\end{array}$ & $\begin{array}{c}\begin{array}{c}\text { Diameter of medium Size } \\
(\mathbf{m m})\end{array} \\
\end{array}$ & $\begin{array}{c}\text { Diameter of large size follicle } \\
\text { large }(\mathrm{mm})\end{array}$ \\
\hline 1 & $7.18 \pm 0.45^{\mathrm{b}}$ & $11.08 \pm 1.19^{\mathrm{ab}}$ \\
\hline 2 & $6.01 \pm 0.32^{\mathrm{ab}}$ & $11.40 \pm 1.11^{\mathrm{ab}}$ \\
\hline 3 & $5.42 \pm 0.63^{\mathrm{a}}$ & $12.04 \pm 0.64^{\mathrm{ab}}$ \\
\hline 4 & $5.91 \pm 0.54^{\mathrm{ab}}$ & $10.92 \pm 1.02^{\mathrm{ab}}$ \\
\hline 5 & $6.12 \pm 0.39^{\mathrm{ab}}$ & $10.97 \pm 1.37^{\mathrm{ab}}$ \\
\hline 6 & $5.83 \pm 0.52^{\mathrm{ab}}$ & $10.21 \pm 0.64^{\mathrm{a}}$ \\
\hline 7 & $5.41 \pm 0.18^{\mathrm{a}}$ & $11.05 \pm 0.67^{\mathrm{ab}}$ \\
\hline 8 & $6.02 \pm 0.29^{\mathrm{ab}}$ & $11.02 \pm 0.72^{\mathrm{ab}}$ \\
\hline 9 & $5.69 \pm 0.39^{\mathrm{ab}}$ & $11.58 \pm 0.96^{\mathrm{ab}}$ \\
\hline 10 & $5.94 \pm 0.37^{\mathrm{ab}}$ & $11.89 \pm 0.72^{\mathrm{ab}}$ \\
\hline 11 & $5.12 \pm 0.24^{\mathrm{a}}$ & $12.60 \pm 0.73^{\mathrm{ab}}$ \\
\hline 12 & $5.38 \pm 0.25^{\mathrm{a}}$ & $12.07 \pm 0.95^{\mathrm{ab}}$ \\
\hline 13 & $4.79 \pm 0.21^{\mathrm{a}}$ & $12.31 \pm 0.70^{\mathrm{ab}}$ \\
\hline 14 & $5.79 \pm 0.61^{\mathrm{ab}}$ & $11.30 \pm 0.96^{\mathrm{ab}}$ \\
\hline 15 & $6.08 \pm 0.45^{\mathrm{ab}}$ & $13.58 \pm 0.54^{\mathrm{ab}}$ \\
\hline 16 & $5.90 \pm 0.55^{\mathrm{ab}}$ & $12.37 \pm 01.31^{\mathrm{ab}}$ \\
\hline 17 & $5.33 \pm 0.63^{\mathrm{a}}$ & $12.64 \pm 1.01^{\mathrm{ab}}$ \\
\hline 18 & $5.29 \pm 0.51^{\mathrm{a}}$ & $12.35 \pm 1.42^{\mathrm{ab}}$ \\
\hline 19 & $4.98 \pm 0.31^{\mathrm{a}}$ & $13.12 \pm 0.95^{\mathrm{ab}}$ \\
\hline 20 & $5.84 \pm 0.59^{\mathrm{ab}}$ & $12.90 \pm 0.44^{\mathrm{ab}}$ \\
\hline 21 & $5.31 \pm 0.71^{\mathrm{a}}$ & $14.12 \pm 1.40^{\mathrm{b}}$ \\
\hline
\end{tabular}

Note: Mean values with different superscripts $(a, b)$ differ significantly $(\mathrm{P}<0.05)$ 
Table.5 Number (Mean \pm SE) of total follicles in non-cyclic and cyclic Murrah buffaloes on various days of ultrasonographic examinations

\begin{tabular}{|c|c|c|}
\hline Day of cycle & Non-cyclic & cyclic \\
\hline 1 & $3.83 \pm 0.48$ & $4.83 \pm 0.17$ \\
\hline 2 & $3.67 \pm 0.42$ & $5.17 \pm 0.80$ \\
\hline 3 & $3.17 \pm 0.478$ & $5.67 \pm 0.80$ \\
\hline 4 & $2.83 \pm 0.31$ & $4.50 \pm 0.62$ \\
\hline 5 & $3.33 \pm 0.61$ & $4.33 \pm 0.56$ \\
\hline 6 & $4.83 \pm 0.48$ & $4.5 \pm 00.62$ \\
\hline 7 & $3.83 \pm 0.54$ & $4.83 \pm 0.31$ \\
\hline 8 & $3.5 \pm 0.43$ & $5.00 \pm 0.45$ \\
\hline 9 & $4.17 \pm 0.31$ & $4.67 \pm 0.62$ \\
\hline 10 & $2.83 \pm 0.17$ & $4.67 \pm 0.42$ \\
\hline 11 & $2.83 \pm 0.54$ & $5.33 \pm 0.33$ \\
\hline 12 & $3.33 \pm 0.42$ & $4.67 \pm 0.33$ \\
\hline 13 & $4.33 \pm 0.71$ & $5.17 \pm 0.40$ \\
\hline 14 & $3.33 \pm 0.49$ & $4.67 \pm 0.56$ \\
\hline 15 & $3.67 \pm 0.56$ & $4.83 \pm 0.40$ \\
\hline 16 & $3.5 \pm 0.56$ & $4.00 \pm 0.68$ \\
\hline 17 & $3.67 \pm 0.33$ & $4.33 \pm 0.49$ \\
\hline 18 & $3 \pm 0.45$ & $4.17 \pm 0.54$ \\
\hline 19 & $3.5 \pm 0.34$ & $4.33 \pm 0.49$ \\
\hline 20 & $3.33 \pm 0.33$ & $4.00 \pm 0.45$ \\
\hline 21 & $2.83 \pm 0.31$ & $4.33 \pm 0.33$ \\
\hline
\end{tabular}

Table.6 Diameter (Mean \pm SE) of corpus luteum in cyclic Murrah buffaloes on various days of estrous cycle

\begin{tabular}{|c|c|}
\hline Days of estrous cycle & Diameter $(\mathbf{m m})$ \\
\hline 5 & $9.36 \pm 0.54^{\mathrm{a}}$ \\
\hline 6 & $12.84 \pm 0.44^{\mathrm{bc}}$ \\
\hline 7 & $13.79 \pm 0.24^{\mathrm{bcd}}$ \\
\hline 8 & $13.54 \pm 0.75^{\mathrm{bcd}}$ \\
\hline 9 & $14.44 \pm 1.09^{\mathrm{cde}}$ \\
\hline 10 & $13.61 \pm .87^{\mathrm{bcd}}$ \\
\hline 11 & $15.28 \pm 0.62^{\mathrm{de}}$ \\
\hline 12 & $14.96 \pm 0.72^{\mathrm{de}}$ \\
\hline 13 & $14.36 \pm 0.66^{\mathrm{cde}}$ \\
\hline 14 & $16.43 \pm 0.40^{\mathrm{e}}$ \\
\hline 15 & $14.16 \pm 0.72^{\mathrm{de}}$ \\
\hline 16 & $13.52 \pm 0.92^{\mathrm{bcd}}$ \\
\hline 17 & $12.72 \pm 0.77^{\mathrm{bc}}$ \\
\hline 18 & $12.5 \pm 0.47^{\mathrm{bc}}$ \\
\hline 19 & $12.44 \pm 0.42^{\mathrm{bc}}$ \\
\hline 20 & $12.12 \pm 0.41^{\mathrm{bc}}$ \\
\hline
\end{tabular}

Note: Mean values with different superscripts $(\mathrm{a}, \mathrm{b}, \mathrm{c}, \mathrm{d}, \mathrm{e})$ differ significantly $(\mathrm{P}<0.05)$ 
Further they reported no significant difference in number of medium size follicles recorded on various days of estrous cycle compared to day 1(days first post ovulation). Akshey et al., (2005) observed that there was no difference in cyclic Murrah buffaloes in the number of medium follicles between day 3 and day 5 .

The mean number of large follicles in cyclic animals varied non-significantly. No significant difference in number and diameter of the large follicles was observed on various days of estrous cycle. Aksheyet al., (2005) reported that the number of large follicles was significantly higher at day 5 which is contrary to our findings in cyclic Murrah buffaloes. It may be due to breed difference. Barkawi et al., (2009) observed no significant difference in number of large follicles recorded on various days of estrous cycle compared to day 1 (day first post ovulation) in Egyptian buffaloes.

The mean diameter of medium size follicles in cyclic animals was variable during estrous cycle. The significant increase in diameter of medium follicles was recorded on day 5 as compared to other days except day 19 and 20 of the estrous cycle. Yilmaz et al., (2014) reported that follicles between 5 and $8 \mathrm{~mm}$ in diameter were fewer during late diestrous and follicular phase in water buffaloes.

The mean diameter of large size follicles in cyclic Murrah buffaloes was variable with maximum size of $11.45 \pm 2.35 \mathrm{~mm}$ but there was non-significant difference throughout the study. During estrous cycles in cattle dominant follicles reach a maximum diameter of approximately 10-20 mm (Fortune et al., 1988; Savio et al., 1988 and Ginther et al., 1989). Barkawi et al., (2009) observed maximum diameter of dominant follicle that was insignificantly greater than the other dominant follicles that observed throughout the estrous cycle in Egyptian buffaloes.
Yilmaz et al., (2014) reported that follicles between 8-12 $\mathrm{mm}$ in diameter were less during metestrous and follicular phase. They further reported that follicles at least $12 \mathrm{~mm}$ in diameter were more numerous in follicular phase in water buffaloes. Ginther et al., (1989) reported that the sub-dominant follicles reach maximum diameters of approximately $8 \mathrm{~mm}$ in cyclic cattle. Contrary to our finding, Presicce et al., (2005) measured the largest size follicle in first postpartum ovulation as $13.5 \pm 0.8$ and $14.1 \pm$ $0.4 \mathrm{~mm}$ in primiparous and pluriparous buffaloes, respectively which is higher than present study finding.

The CL is a transient endocrine gland formed after ovulation of follicle. In present investigation, the diameter of corpora lutea ranged between $9.36 \pm 0.54$ to $16.43 \pm 0.40 \mathrm{~mm}$ in cyclic animals. A non-significant increase in diameter of CL was observed from day 6 to 13. The mean value of CL diameter was significantly lowest on day 5 indicating immaturity of CL and highest value was recorded on day 14 indicating maturity of CL. Barkawi et al., (2009) observed maximum diameter of CL $(15 \pm 0.04 \mathrm{~mm})$ on $7^{\text {th }}$ day of cycle which did not differ significantly in both normal and in Egyptian buffaloes with uterine pathology. Vecchioa et al.,(2012) measured the diameter of the CL on day 5 and 10 after $\mathrm{AI}$ in buffaloes as $17 \pm 0.0$ vs. $17.0 \pm$ $0.0 \mathrm{~mm}$ and $17 \pm 0.0$ vs. $21.0 \pm 0.0 \mathrm{~mm}$, respectively in non-pregnant vs. pregnant. They reported diameter of CL on day 15 was $17 \pm 0.0 \mathrm{~mm}$ vs. $19.0 \pm 0.0 \mathrm{~mm}$ and which subsequently attained the size as $15 \pm 0.0 \mathrm{~mm}$ vs. $21.0 \pm 0.0 \mathrm{~mm}$ (non-pregnant vs pregnant) on day 20. Kayacik et al., (2005) measured the size of the CL from the beginning of the second day post ovulation and recorded its maximum size on days 6,9 , and 10 in short, normal and long cycles, respectively in cows. Honparkhe et al., (2004) measured the mean ultrasonic size of $\mathrm{CL}$ at day 9 between 
$10.7 \pm 0.28$ to $12.0 \pm 0.13 \mathrm{~mm}$, which further reached the size ranging between $8.8 \pm 0.11$ to $9.5 \pm 0.23 \mathrm{~mm}$ on day 16 and theses values are lying in the range of present investigation. Rakesh et al., (2013) measured the dimension of CL that increased gradually with the advancement of stage of estrous cycle and peak values were observed between 12 and 16 days of estrous cycle. Alejandro et al., (2014) measured the maximum luteal diameter as $19.58 \pm 4.16 \mathrm{~mm}$ and $17.74 \pm 3.32 \mathrm{~mm}$ respectively in Murrah buffaloes and buffalo heifers on day 15 and 17 of the estrous cycle, respectively which is quite higher than present findings.

\section{Ovarian dynamics in non-cyclic buffaloes}

In present investigation, the mean number of small follicles in non-cyclic Murrah buffaloes was variable. The highest number of follicles was observed on day 3, 10 and 20 of study as compared to other days. Lucy et al., (1991) and El-Wishy (2007) reported that the early postpartum period is characterized by reduction in the number of small sized follicles. In contrast to our study, Dutt et al., (2014) reported the mean number of small follicle in a range between $3.17 \pm 0.17$ to $4.17 \pm 0.48$ without any significance in noncyclic Murrah buffaloes.

In present study, the mean number of medium sized follicles in non-cyclic Murrah buffaloes varied non-significantly with maximum number on day 11 of the study period. Dutt et $a l$., (2014) reported the mean number of medium follicles in non-cyclic buffaloes were in a range of $3.17 \pm 0.65$ to $4.33 \pm 0.76$ under field conditions. This difference may either be due to difference in season of study or managemental practices.

In present study, the mean number of large follicles in non-cyclic Murrah buffaloes varied. The maximum number of follicles was recorded on day $3(1.80 \pm 0.20)$ of the cycle compared to day 15, 16 and 18-20 (1.00 \pm 0.00 on all these days) of study. Dutt et al., (2014) reported the mean number of large follicles within a range between $2.33 \pm 0.21$ to $3.00 \pm 0.26$ in non-cyclic buffaloes.

In current study, the mean diameter of medium and large sized follicles in non-cyclic Murrah buffaloes varied non-significantly. The maximum diameter of medium follicles $(7.18 \pm .45)$ was recorded on $1^{\text {st }}$ day and maximum diameter $(14.12 \pm 1.40)$ of large follicles was recorded on $21^{\text {st }}$ day of the study. Kumar et al., (2012), Kandiel et al., (2013) and Dutt et al., (2014) reported that the mean values of follicular diameter of medium sized follicles varied from $4.21 \pm 0.02$ to $4.48 \pm 0.12 \mathrm{~mm}$ in non-cyclic buffaloes. Dutt et al., (2014) found that the follicular diameter of large size follicles varies between $8.46 \pm 0.16$ to $9.07 \pm 0.30 \mathrm{~mm}$ in non-cyclic buffaloes under field conditions. They further concluded that the mean number of small, medium, large and total follicles did not differ significantly between and within the control and in group under estrus induction treatment prior to estrus induction treatment indicating emergence of constant number of follicles at any day during anoestrus condition. This is contrary to present study which may be due to differences in managemental condition at farm.

The mean number of total follicles in cyclic Murrah buffaloes varied between $4.00 \pm 0.45$ to $5.67 \pm 0.80$. No statistical difference was observed during the cyclic period. Similarly, Akshey et al., (2005) observed that there was no significant difference in the number of total follicles between day 3 and 5 in cyclic Murrah buffaloes. In present investigation, the mean values of total number of follicles varied from $2.83 \pm 0.31$ to $4.83 \pm 0.48$ in noncyclic Murrah buffaloes during different days of examinations. The number of follicles was 
comparatively higher in cyclic as compare to non-cyclic Murrah buffaloes. Kumar et al., (2012) reported that average number of follicles on both ovaries ranged between $7.50 \pm 0.50$ to $9.33 \pm 1.69$ within groups and the maximum size of dominant follicle in their study was $13.03 \pm 0.89 \mathrm{~mm}$ in non-cyclic buffaloes. Kachiwal et al., (2012) opined that average size of follicle on the day of heat $(15.25 \pm 1.28 \mathrm{~mm})$ is greater as compared post breeding $(12.00 \pm 0.82 \mathrm{~mm})$ in Kundhi buffaloes. These variations may be due to breed difference.

Although the total number of follicles in cyclic animals was higher in comparison to non-cyclic animals but as per our findings, the non-cyclic animal was not in true anestrus condition, as there was follicles growth on ovaries. There was follicular development in non-cyclic animals but no CL formation i.e. ovulation failure occurs in these animals. It might be possible that these acyclic animals may come in estrus but was not diagnosed due to decreased heat intensity, short duration of estrus or unobserved heat signs. Anovulation may be due to irregularities in gonadotrophin synthesis or hormonal imbalance in these non-cyclic animals. Thus, it was concluded that, in these types of animals, induction of cyclicity is indicated by using different hormonal regimens like Ovsynch or Progesterone based protocols.

\section{References}

Adams G P, Jaiswal, R., Singh, J. and Malhi, P. 2008. Progress in understanding ovarian follicular dynamics in cattle. Theriogenology, 69:72-80.

Akshey, Y.S., Palta, P., Manik, R.S., Vivekananad and Chauhan, M.S. 2005. Effect of removal of follicles through repeated trans-vaginal follicle aspiration on subsequent follicular populations in Murrah buffalo (Bubalus bubalis).
Asian-Aust. J. Anim. Sci., 18(5): 632636.

Alejandro, O.R., Esp, Ricardo Londoño, O., Carlos Gutierrez, R. and Gonella-Diaza, A. 2014. Follicular dynamics, corpus luteum growth and regression in multiparous buffalo cows and buffalo heifers. Rev.MVZ Córdoba. 19(2):4130-4140.

Aslan, S., Findik, M., Erunal-Maral N., Kalender, H., Celebi, M., and Saban, E. 2000. Comparison of various examination methods used in ovarian diagnostics in cattle. Dtsch. Tierarztl. Wochenschr. 107:227-230.

Barkawi, A.H., Hafez, Y.M., Ibrahim, S.A., Ashour, G., El-Asheeri, A.K. and Ghanem, N. 2009. Characteristics of ovarian follicular dynamics throughout the estrous cycle of Egyptian buffaloes. Anim. Reprod. Sci., 110: 326-334.

Baruselli, P.S., Mucciolo, R.G., Visintin, J.A., Viana, W.G., Arruda, R.P., Madureira, E.H., Oliveiras, C.A. and MoleroFilhof, J.R. 1997. Ovarian follicular dynamics during the estrous cycle in buffalo (Bubalus Bubalis). Theriogenology, 47:1531-1547.

Beal, W.E., Perry, R.C. and Corah, L.R. 1992. The use of ultrasound in monitoring reproductive physiology of beef cattle. J Anim. Sci., 70: 924-929.

Dutt, R., Singh, U., Chandolia, R.K., Singh, G., Seema, Das, G.K., Sharma, R. and Sharma, A. 2014. Effect of exogenous administration of buffalo follicular Fluid on follicular development in anoestrus buffaloes (Bubalus bubalis). Vet. Pract., 15(1):1-4.

Edmondson, A.J., Fissore, R.A.,Pashen, R.L. and Bondurant R. 1986. The use of ultrasonography for the study of the bovine reproductive tract 1 . Normal and pathological ovarian structures. Anim. Reprod. Sci., 12: 157-165.

El-Wishy, A.B. 2007. The postpartum 
buffalo: I. Endocrinological changes and uterine involution. Anim. Reprod. Sci., 97: 201-215.

Farin, P.W., Youngquist, R.S., Parfet, J.R. and Garverick, H.A. 1990. Diagnosis of luteal and follicular ovarian cysts in dairy cows by sector scan ultrasonography. Theriogenology, 34:633-642.

Fortune, J.E., Sirois, J. and Quirk, S.M. 1988. The growth and differentiation of ovarian follicles during the bovine oestrus cycle. Theriogenology., 29: 95109.

Fricke, P.M. (2002). Scanning the futureultrasonography as a reproductive management tool for dairy cattle. J. Dairy Sci; 85: 1918-1926.

Ginther, O.J, Wiltbank, M.C., Fricke, P.M., Gibbons, J.R. and Kot, K. 1996. Selection of the dominant follicle in cattle: minireview. Biol Reprod., 55:1187-1194.

Ginther, O.J., Knopf, L. and Kastelic, J.P. 1989. Ovarian follicular dynamics in heifers during early pregnancy. Biol. Reprod., 41: 247-254.

Hanzen, J., Sato, M., Ruedy, R., Lacis, A., and Oinas, V. 2000. Global warming in the twenty-first century: An alternative scenario. PNAS. 97(18): 9875-9880.

Honparkhe, M., Gandotra, V.K. and Nanda, A.S. 2004. Comparative detectability of follicles and corpus luteum through rectal palpation and ultrasonography in buffaloes during different stages of estrous cycle. Indian J. Anim. Sci., 74(8):835-837.

Kachiwal, A.B., Sheikh, B.A., Sheikh, S.A., Qureshi, T.A. and Memon, M.A. 2012. Ultrasonographic biometry of the ovaries of pregnant Kundhi buffaloes. J. Buff. Sci., 1: 188-192.

Kahn, W. and Ludlow, W. 1989. Characteristics of pathological conditions of the bovine uterus and ovaries. In: Taverne MM, Willemse AH (eds.), Diagnostic Ultrasound and Animal Reproduction. Kluwer Academic Publishers Dordrecht, 53-65. Kandiel, M.M., Gad, B.A., Sosa, G.A. and ElAzab, A.I. 2013. Follicular dynamics and uterine status after synchronization of ovulation in early post-parturient Egyptian buffaloes. Buff. Bull., 32(3): 165-181.

Kastelic, J.P., Bergfelt, D.R. and Ginther, O.J. 1990. Relationship between ultrasonic assessment of the corpus luteum and plasma progesterone concentration in heifers. Theriogenology, 33: 12691278.

Kayacik, V., Salmanoglu, M.R., Polat, B. and Ozluer, A. 2005. Evaluation of the corpus luteum size throughout the cycle by ultrasonography and progesterone assay in cows. Turk. J. Vet. Anim. Sci., 29: 1311-1316.

Kumar, S., Malik, R.K., Sharma, R K., Dutt, R., Singh, P., Singh, G., and Virmani, M. 2012. Effect of Ovsynch protocol in different hormonal combinations on follicular dynamics in anoestrus Murrah buffaloes. Vet. Pract., 13(2): 273-275.

Lucy, M.C., Staples, C.R., Michel, F.M., Thatcher, W.W. and Bolt, D.J. 1991. Effect of feeding calcium soaps to early postpartum dairy cows on plasma prostaglandinF2 alpha, luteinizing hormone and follicular growth. J. Dairy Sci., 74: 483-489.

Manik, R.S., Singla, S.K., Palta, P. and Madan, M.L. 1999. Changes in follicular populations following treatment of buffaloes with PMSG/eCG and Neutra-PMSG for superovulation. Anim. Reprod. Sci., 56: 31-38.

Pierson, R.A. and Ginther, O.J. 1988. Ultrasonic imaging of the ovaries and uterus in cattle. Theriogenology, 29:2137.

Presicce, G.A., Bellab, A., Terzanoc, G.M., 
Santisc, G.D. and Senatorea, E.M. 2005. Postpartum ovarian follicular dynamics in primiparous and pluriparous Mediterranean Italian buffaloes (Bubalus bubalis). Theriogenology, 63: 1430-1439.

Rakesh, H.B., Singh, S.K., Sharma, C.G., Jessiehun, N. and Agarwal S. K. 2013. Morphological and functional characterization of corpus luteum during different stages of estrous cycle in buffalo. Indian J. Anim Sci., 83(7): 710-712.

Reeves, J.J., Rantanen, N.W. and Hauser, M. 1984. Transrectal real-time ultrasound scanning of the cow reproductive tract. Theriogenology, 21: 485-494.

Savio, J.D., Kenan, L., Boland, M.P. and Roche, J.F. 1988. Pattern of growth of dominant follicles during the estrous cycle in heifers. J. Reprod. Fertil, 83: 663-671.

Singh J, Pierson, R.A. and Adams, G.P. 1997. Ultrasound image attributes of the bovine corpus luteum: structural and functional correlates. J. Reprod Fertil., 109(1):35-44.

Smith, S.T., Ward, W.R. and Dobson, H. 1998. Use of ultrasonography to help to predict observed oestrus in dairy cows after the administration of prostaglandin $F_{2} \alpha$. Vet Rec., 142, 271-274.

Vecchioa, D., Negliaa, G., Gasparrinia, B., Russob, M., Pacellic, C., Prandid, A., D'Occhioe, M.J. and Campanilea, G. 2012. Corpus luteum development and function and relationship to pregnancy during the breeding season in the Mediterranean buffalo. Theriogenology, 77: 1811-1815.

Yilmaz, O., Yazici, E., Kahraman, A., Ozenc, E. and Ucar, M. 2014. The relationship between ovarian follicle population and follicle size during different stages of estrous cycle in Anatolian Water buffaloes (Bubalus bubalis). Revue. Méd. Vét, 165 (3-4):111-115.

\section{How to cite this article:}

Gyan Singh, R.K. Chandolia, Ravi Dutt, Anil Saini, Jasmer Dalal and Malik, R.K. 2017. Comparative Study of Follicular Turn Over in Cyclic and Non-Cyclic Murrah Buffaloes through 2D Trans-Rectal Ultrasonography. Int.J.Curr.Microbiol.App.Sci. 6(11): 3590-3602. doi: https://doi.org/10.20546/ijcmas.2017.611.421 